\title{
Pemetaan Potensi dan Dampak Ekonomi Masyarakat di Kawasan Pertambangan Bukit Tumpang Pitu Banyuwangi
}

\author{
Sukriyah Kustanti Moerad ${ }^{1}$, Endang Susilowati ${ }^{2}$ Windiani $^{3}$ \\ UPT PMK Sosial Humaniora, Institut Teknologi Sepuluh Nopember, 61111, Surabaya, E-mail: \\ antinmoerad01@gmail.com
}

\begin{abstract}
Bukit Tumpang Pitu is located in Sumber Agung village, district of Pesanggaran, Banyuwangi region. There ara seven hills around Bukit Tumpang and it contains gold minning resourses. Since 2000, this area had been minning by local community with conventional method. On 20008, Local Government of Banyuwangi gave access for doing explaration in this area to Indo Multi Niaga corporation (IMN ltd). And this made the minners segemented into two types, i.e: a conventional and labor corporation minner. This research intends to make a map of local potention in this minner area and to see that there is an economic impact for the community in minning area. The method used is a grounded research, by using survey method, observation and interview with respondent through sample-questioner. This research wants to show that there are many economic pontentions to earn in this area. Since minner area, many people will come to this place. Besides the economic function, this area have tourism destination. It is Red Island beach and reside at near to the minner area.
\end{abstract}

Keywords: Potential mapping; Economic impact; labor corporation minner; traditional labor minner; area minning

\section{ABSTRAK}

Sejak tahun 2012, Desa Sumber Agung selain sebagai kawasan pertambangan yang sudah hampir 15 tahun, juga mempunyai potensi wisata Red Island (Pulo Merah). Permasalahan penelitian adalah sejauh mana perubahan sosial ekonomi terjadi di masyarakat Desa Sumber Agung. Tujuan Penelitian melihat bagaimana perubahan sosial ekonomi terjadi pada masyarakat Desa tersebut. Penelitian ini penelitian lapangan (grounded research), menggunakan metode survei lokasi, observasi, dan wawancara menggunakan kuesioner. Teknik sampel secara purposive random sampling dengan jumlah responden 100 orang. Pengolahan data kuantitatif dengan menggunakan kategorisasi dan tabel frekuensi. Analisis data secara diskriptif analitik. Hasil penelitian menunjukkan adanya perubahan potensi ekonomi. Mulai dari jenis mata pencaharian, pendapatan masyarakat, hingga pola dan gaya hidup sehari-hari. Desa Sumber Agung tidak lagi mencerminkan desa pedalaman namun lebih menunjukkan desa wisatawan. Pemukiman penduduk desa sudah berubah fungsi menjadi Homestay, dan Guest House karyawan petambang swasta.

Kata Kunci: Pemetaan; perubahan ekonomi; Perusahaan Penambang; Penambang Tradisional, Wilayah Penambangan. 


\section{Pendahuluan}

Negara Indonesia memiliki tanah yang kaya mineral yang selalu diremajakan dan diperkaya oleh badan-badan yang dikeluarkan oleh gunung-gunung berapi. Di dalamnya juga terkandung aneka ragam bahan galian yang merupakan bahan mentah industri seperti timah, timah hitam, bijih alumunium, nikel, tembaga dan asbes, emas, perak, mangan, kuarsa, batu gamping, belerang, dan lain sebagainya. Tetapi ada hal yang perlu diperhatikan bahwa "Kekayaan alam yang kita miliki bukan warisan dari nenek moyang yang boleh dihabiskan begitu saja, melainkan harta pusaka yang harus diwariskan secara turun temurun dalam keadaan utuh. Sebab pemanfaatan sumber daya secara kurang hati-hati dapat merugikan kepentingan manusia masa kini dan generasi masa yang akan datang" (Daryanto, 2000).

Degradasi lingkungan alam di satu sisi sebagai akibat dari proses alam itu sendiri namun di sisi lain akibat dari kegiatan manusia dalam memenuhi konsumsi ekonomi. Seperti yang dinyatakan oleh Mochtar Lubis (2005) bahwa kerusakan alam lebih dimungkinkan oleh manusia, sebab alam itu seperti yang kita lihat sekarang ini sebelum banyak terjadi kerusakan ekologi adalah perwujudan dari proses evolusi yang telah berlangsung. Selama terjadi perubahan alam maka karakteristik yang menyertai adalah mencari keseimbangan. Jadi jagad raya diciptakan Tuhan dengan pengaturan hukum keseimbangan. Namun apabila kegiatan atau ulah manusia terlalu melebihi daya tampung alam bumi maka terjadilah kerusakan-kerusakan alam. Menurut
Muchtar Lubis (2005) kesadaran akan pentingnya lingkungan hidup bukan hanya tanggungjawab pemerintah saja namun kesadaran masyarakat juga harus ditumbuhkembangkan.

Pertambangan merupakan salah satu aset sumber daya alam yang termasuk dalam kekayaan bumi di dunia. Pengelolaan di bidang pertambangan dan energi adalah peningkatan kerusakan sumber alam tanah dan air akibat kegiatan eksploitasi. Oleh karena itu potensi daerah yang memiliki kekayaan sumber daya alam tersebut dapat menjadi alternatif untuk dikelola, tentu saja dengan izin dari pemerintah. Maraknya izin usaha pertambangan mengakibatkan pula menjamurnya kota-kota yang berkeinginan untuk mengelola tambang yang ada di wilayah kota tersebut. Salah satu kota di ujung timur Jawa Timur yakni Kota Banyuwangi tak terlepas juga berkeinginan untuk mengelola potensi pertambangan yang ada di satu kawasan Kecamatan yakni Kecamatan Pesanggaran Kabupaten Banyuwangi. Pertambangan di areal ini sangat unik yakni ada 7 Bukit yang mengandung tambang tersebut. Gunung itu terkenal dengan nama "Bukit Tumpang Pitu". Sejak tahun 2000, masyarakat wilayah ini secara tradisional sudah banyak yang mengetahuinya dan banyak yang mencoba beralih dari kegiatan pertanian dan peladangan menjadi petambang. Kemudian tahun 2008 masuklah investor PT. Indo Multi Niaga (IMN) yang sudah diberi izin oleh Bupati Ratna pada tahun 2008-2014 untuk melakukan eksplorasi pertambangan emas di kawasan hutan tersebut dengan luasan mencapai 11.621,45 ha. Sebagian meliputi area hutan 
konservasi di Kecamatan Siliragung dan Pesanggaran. Data dari Kecamatan Pesanggaran dalam Angka (BPS: 2011) awalnya, jumlah penambang tradisional mencapai 12 ribu orang yang berasal dari wilayah setempat atau pun dari luar kota Jember, Situbondo, Bali, dan Solo. Namun, dengan gencarnya Polres Banyuwangi melakukan penangkapan karena menganggap petambang tradisional justru merusak lingkungan, akhirnya jumlahnya sempat menyusut menjadi 250 orang. Namun belakangan, IMN menjual 80 persen sahamnya kepada empat korporasi sehingga pemerintah Banyuwangi kembali bernegosiasi dengan korporasi tersebut (Kompas, Juli, 2012).

Berdasarkan hasil survei pendahuluan serta diperkuat hasil penelitian Siwi Yunita (2012), menunjukkan bahwa sejak adanya proyek pertambangan di wilayah Bukit Tumpang Pitu, kehidupan masyarakat berubah menjadikan kehidupan sosial yang serba keras, tidak lagi aman dan harmonis, saling bersaing hingga mengakibatkan rumah tangga mereka jadi berantakan. Hal ini disebabkan para kepala keluarga sebagai petambang tradisional menanamkan modalnya untuk ikut explorasi, dengan tujuan untuk mendapatkan pendapatan lebih besar dari sebagai seorang petani dan peladang. Namun hingga setahun, apa yang mereka harapkan tak kunjung datang. Di sisi lain mereka harus mencukupi keluarga mereka. Sehingga terjadilah konflik sosial yang cukup besar di masyarakat Kecamatan Pesanggaran khususnya kawasan Bukit Tumpang Pitu. Konflik mulai memanas karena warga mengira eksplorasi oleh PT IMN diperbolehkan sedangkan masyarakat tradisional tidak diperbolehkan bahkan dikejar-kejar dan dipenjarakan. Konflik meledak bulan Juni 2011 dimana ribuan petambang tradisional membakar salah satu pos milik PT IMN. Lebih lanjut seorang warga (Deni, 68 tahun) mengatakan bahwa lahan yang sudah digali atau belum, menguntungkan atau tidak, adanya tambang emas terbukti telah merusak kekayaan paling berharga yang dimiliki oleh warga Kecamatan Pesanggaran yaitu kehidupan kebersamaan dan kegotongroyongan.

Namun demikian kondisi yang berbeda terjadi di Desa Sumber Agung Kecamatan Pesanggaran, lokasi yang banyak dipilih para pendatang khususnya karyawan perusahaan pertambangan yang sedang melakukan eksplorasi. Sebagian masyarakat di desa ini beralih pekerjaan dari petani dan nelayan menjadi penambang, karyawan perusahaan atau berwiraswasta membangun kost-kosan dan membuka warung. Kondisi perekonomian berkembang dengan pesat sejalan dengan beroperasinya kegiatan perusahaan dalam melakukan eksplorasi tambang. Masalah yang dikaji dalam penelitian ini lebih berfokus pada upaya pemetaan potensi lokal yang dapat dikembangkan dan dampak ekonomi bagi masyarakat dari kegiatan penambangan emas di kawasan Bukit Tumpang Pitu.

Sedangkan tujuan penelitian ini adalah melakukan pemetaan potensi lokal yang dapat dikembangkan dan menganalisis dampak yang ditimbulkannya khususnya dalam bidang ekonomi di kawasan Bukit Tumpang Pitu. Penelitian ini menggunakan data primer yang dikumpulkan 
langsung pada lokasi objek penelitian yaitu Desa Sumber Agung Kecamatan Pesanggaran dan data sekunder dari instansi terkait. Metode sampel yang digunakan adalah metode purposif sample, yaitu sampel merupakan perwakilan tertentu yang dianggap bisa mewakili pendapat dari populasi. Indikator yang dikaji adalah indikator-indikator sosial ekonomi, seperti tingkat pendidikan, pendapatan, kepemilikan (aset), pekerjaan utama, dan pekerjaan sampingan. Hasil dari penelitian dapat menjadi masukan dan bahan pertimbangan bagi pemerintah daerah dalam menyusun strategi dan rencana pengembangan potensi lokal yang ada di Banyuwangi khususnya di kawasan pertambangan Bukit Tumpang Pitu Kecamatan Pesanggaran.

\section{Dampak Kegiatan Penambangan}

$$
\text { Kegiatan industri penambangan }
$$

menimbulkan dampak baik pengaruh positif maupun negatif. Dampak positif kegiatan penambangan yaitu memberikan kontribusi terhadap peningkatan pendapatan asli daerah, membuka keterisolasian wilayah, menyumbangkan devisa negara, membuka lapangan kerja, pengadaan barang dan jasa untuk konsumsi dan yang berhubungan dengan kegiatan produksi, serta dapat menyediakan prasarana bagi pertumbuhan sektor ekonomi lainnya (Mangkusubroto, 1995). Menurut Salim (2007) dampak positif dari kegiatan pembangunan di bidang pertambangan adalah:

1. Memberikan nilai tambah secara nyata kepada pertumbuhan ekonomi nasional;
2. Meningkatkan Pendapatan Asli Daerah (PAD) ;

3. Menampung tenaga kerja, terutama masyarakat di sekitar tambang;

4. Meningkatkan ekonomi masyarakat di sekitar tambang;

5. Meningkatkan usaha mikro masyarakat di sekitar tambang;

6. Meningkatkan kualitas SDM masyarakat di sekitar tambang; dan

7. Meningkatkan derajat kesehatan masyarakat di sekitar tambang.

Namun secara alami keberadaan deposit sumber daya tambang selalu berinteraksi dan berkaitan dengan lingkungan habitatnya, seperti tanah, air, dan tumbuh-tumbuhan. Karena itu salah satu faktor mendasar yang tidak dapat dihindari pada saat melakukan eksploitasi deposit tambang tersebut adalah terjadinya degradasi lingkungan. Di dalam Undang Undang Lingkungan Hidup Nomor 32 tahun 2009, kerusakan lingkungan hidup adalah perubahan langsung dan/atau tidak langsung terhadap sifat fisik, kimia, dan/atau hayati lingkungan hidup yang melampaui kriteria baku kerusakan lingkungan hidup. Beberapa kejadian sebagai dampak negatif dari kegiatan pertambangan dapat dilihat dari terjadinya ancaman terhadap lingkungan fisik, biologi, sosial, budaya, ekonomi, dan warisan nasional (Barton, 1993).

Dampak negatif terhadap ekologi di berbagai daerah bekas tambang dapat dilihat di tambang emas di Kalgoorie Australia Barat, bekas tambang timah di Pulau Dabo Singkep yang menyebabkan air tergenang pada lubang-lubang 
bekas galian sebagai sarang malaria, hamparan tanah gundul yang tidak produktif (Kasus ANTAM Pomala dan PT. Inco), rona kota terkesan sebagai kota mati (Katili, 1998), serta menurunnya kualitas tanah dan air, serta lubanglubang bekas tambang batubara di Kalimantan Timur dan Kalimantan Selatan.

Dampak penambangan di bidang sosial ekonomi sangat terasa menjelang dan berhentinya operasi perusahaan, seperti pendapatan masyarakat menurun, terjadi pemutusan tenaga kerja, tidak adanya lapangan kerja, pola produksi dan konsumsi menurun, pendapatan dan penerimaan pemerintah dari pajak tambang dan retribusi menurun. Dampak lanjutannya yaitu konflik antaretnis, konflik budaya, konflik tanah, kemiskinan dan pengangguran, persepsi negatif terhadap perusahaan, kualitas hidup, partisipasi dan peranan wanita.

Dampak sosial-ekonomi ini menurut Homenauck (1988, dalam Hadi, 2005) dapat dikategorikan ke dalam kelompok-kelompok real impact dan special impact. Real impact adalah dampak yang timbul sebagai akibat dari aktivitas proyek, prakonstruksi, konstruksi, operasi, dan pascaoperasi, misalnya migrasi penduduk, kebisingan, atau polusi udara. Special impact adalah suatu dampak yang timbul dari persepsi masyarakat terhadap resiko dari adanya proyek.

Dampak pada kondisi sosial-ekonomi pada penelitian ini dikaji melalui peluang berusaha, peningkatan pendapatan, perubahan mata pencaharian, perubahan perilaku masyarakat, dan kejadian konflik sosial. Abdul
Rahman Zaki, dkk.(jurnal Administrasi Publik $(J A P)$, dalam penelitian "Dampak Sosial Ekonomi Pertambangan Minyak dan Gas Banyu Urip, Kabupaten Bojonegoro" memberikan kesimpulan bahwa adanya peralihan mata pencaharian masyarakat Gayam yang sebelumnya dominan di sektor pertanian beralih ke sektor pertambangan.Tingkat pendapatan meningkat dan mengarah lebih sejahtera Multiple effect sektor pertambangan telah mempengaruhi kenaikan upah sektor non-pertambangan. Peran Pemerintah Kabupaten Bojonegoro sukses dalam memberikan kebijakan sektor pertambangan yang mendukung masyarakat.Terlihat dari keadaan sosial ekonomi masyarakat Gayam. Adanya perda konten lokal dan keterlibatan masyarakat, dapat meredam konflik sosial yang terjadi pada masyarakat sekitar pertambangan Banyu Urip.

Lebih lanjut Chusharini Chamid, mengatakan dalam kesimpulan hasil penelitian tentang "Keberhasilan Program Community Development di Sekitar Tambang Mencerminkan Kinerja Industri Tambang” dikatakan bahwa PT. Kelian Equator Mining (PT. KEM), telah melaksanakan Pengelolaan Mercuri Avereness yang bertujuan untuk mengurangi pencemaran air raksa di lingkungan. Sehingga hal ini bisa meningkatkan kualitas pengetahuan masyarakat terhadap resiko terpaparnya air raksa. Dampak lebih lanjut hal ini bisa meningkatkan kualitas sosial ekonomi masyarakat di kawasan pertambangan (Jurnal MIMBAR, jurnal Sosial dan Pembangunan).

Berbeda pula jika kita melihat hasil penelitian Miranti, (2008), tentang "Prospek 
Industri Batu Bara di Indonesia" Dampak kegiatan pertambangan batu bara di Kelurahan Loa Ipuh Darat pada kondisi sosial adalah memicu timbulnya migrasi masuk, timbulnya kejadian konflik, merenggangnya hubungan kekerabatan, dan memicu timbulnya praktik prostitusi yang dilegalkan oleh pemerintah daerah. Pada kondisi ekonomi kegiatan pertambangan menimbulkan peluang usaha bagi warga masyarakat. Peningkatan atau pun penurunan tingkat pendapatan masyarakat bervariasi berdasarkan jenis pekerjaan warga, serta kesempatan kerja di sektor pertambangan, walaupun untuk warga lokal tergolong minim disebabkan rendahnya tingkat pendidikan dan keterampilan warga lokal.

\section{Pemetaan Potensi Lokal di Kawasan Pertambangan}

Pemetaan potensi lokal merupakan suatu kegiatan yang dilakukan untuk menemukenali potensi sosial ekonomi dan budaya masyarakat lokal atau disebut juga sebagai kegiatan orientasi sosial. Kegiatan ini merupakan bagian dari proses sosialisasi awal, dilakukan setelah dan atau bersamaan dengan kegiatan Kunjungan Informal ke kelompok-kelompok strategis di tingkat desa/kelurahan (lobi kelompok strategis). Kondisi sosial budaya dan sosial ekonomi yang perlu ditemukenali mencakup beberapa kondisi sebagai berikut: nilai-nilai apakah yang dianut oleh masyarakat secara dominan yang mampu menggerakkan masyarakat; kekuatan-kekuatan sosial apakah yang mampu mendatangkan perubahan-perubahan sehingga masyarakat dapat berubah dari dalam diri mereka sendiri; seperti apa karakter dan karakteristik masyarakat, khususnya dalam menyikapi intervensi sosial; seperti apakah pola informasi komunikasi yang terjadi di tengah masyarakat baik penyebaran informasi maupun dalam kerangka pembelajaran; Media-media seperti apakah dan sumber belajar apakah yang digunakan dan diyakini masyarakat sebagai sarana informasi dan pembelajaran; Kekuatan-kekuatan sosial yang dominan di dalam kerangka perubahan social; Faktor-faktor lingkungan apakah yang berpengaruh terhadap sikap dan perilaku masyarakat.

$$
\text { Menurut Lembaga Pengkajian }
$$

Masyarakat Universitas Gadjah Mada (2011) tujuan pemetaan sosial adalah, sebagai langkah awal pengenalan lokasi sasaran program dan pemahaman fasilitator terhadap kondisi masyarakat yang menjadi sasaran. Untuk itu diperlukan pendekatan dan metoda pelaksanaan program pemerintah melalui sosialisasi dan pelatihan. Sedangkan tata cara Pemetaan Sosial (Orientasi Sosial dan Wilayah) ini adalah sebagai dasar penyusunan rencana kerja yang bersifat taktis terhadap permasalahan yang dihadapi serta sebagai acuan dasar untuk mengetahui terjadinya proses perubahan sosial meliputi sikap dan perilaku pada masyarakat.

Lebih lanjut dikatakan bahwa Pemetaan sosial diharapkan menghasilkan data dan Informasi tentang 1). data Demografi: jumlah penduduk, komposisi penduduk menurut usia, gender, mata pencaharian, agama, pendidikan, 2). Data Geografi: topografi, letak lokasi ditinjau dari aspek geografis, aksesibilitas lokasi, pengaruh 
lingkungan geografis terhadap kondisi sosial masyarakat, 3) Data psikografi: nilai-nilai dan kepercayaan yang dianut, mitos, kebiasaankebiasaan, adat istiadat, karakteristik masyarakat, pola hubungan sosial yang ada, motif yang menggerakkan tindakan masyarakat, pengalaman pengalaman masyarakat terutama terkait dengan mitigasi bencana, pandangan, sikap, dan perilaku terhadap intervensi luar, kekuatan sosial yang paling berpengaruh, serta 4) Pola komunikasi: media yang dikenal dan digunakan, bahasa, kemampuan baca tulis, orang yang dipercaya, informasi yang biasa dicari, tempat memperoleh informasi. Dalam pemetaan dilengkapi adanya penegakan Hukum yang bertujuan untuk mengantisipasi kerusakan lingkungan di usaha pertambangan. Fenti U. Puluhulawa, menyatakan dalam kesimpulan penelitian bahwa penegakan hukum dalam bisnis pertambangan dan batubara belum bisa diharapkan untuk mendukung keberadaan penegak hukum, karena metode yang digunakan masih menggunakan hukum sosial (Jurnal Dinamika Sosial, Volume 11 No.2 tahun 2011). Pemetaan sosial di dalam kawasan potensi pertambangan hendaknya didasarkan pada studi kasus yang terjadi di area tambang tersebut.

Kajian dalam penelitian ini difokuskan pada pemetaan potensi dan dampak ekonomi masyarakat di kawasan pertambangan dengan melakukan identifikasi kondisi sosial ekonomi dan potensi-potensi yang ada di wilayah studi. Karena tujuan penelitian ini adalah untuk mengidentifikasi potensi dan dampak ekonomi bagi masyarakat yang tinggal di di daerah potensi pertambangan di Desa Sumber Agung Kecamatan Pesanggaran Kabupaten Banyuwangi maka data yang didapatkan digunakan sebagai dasar pertimbangan pengambilan keputusan dalam pengembangan potensi daerah bagi pemerintah kabupaten Banyuwangi.

\section{Metodologi Penelitian}

A. Jenis Penelitian: Penelitian yang dilakukan termasuk dalam penelitian survei deskriptif. Menurut Morissan (2014) penelitian survei deskrptif (descriptive survei) berupaya menjelaskan atau mencatat fenomena yang terjadi yang terkait dengan permasalahan yang dikaji. Melalui penelitian ini, peneliti melakukan survei untuk melakukan pemetaan dalam rangka mengidentifikasi dan menginventarisasi potensi serta mendeskripsikan dampak ekonomi masyarakat di kawasan pertambangan Bukit Tumpang Pitu Desa Sumber Agung kecamatan Pesanggara Banyuwangi. Metode yang digunakan dalam pelaksanaan survei adalah Formal Rapid Apraisal Participatory Apraisal yakni (Pemantauan Cepat) Participatory Apraisal (Pemantauan Secara Partisipatif).

B. Teknik Pengumpulan Data: Data yang digunakan dalam penelitian ini adalah data primer dan sekunder. Data primer diperoleh melalui observasi langsung di lapangan, penyebaran kuesioner, partisipasi dan wawancara mendalam (dept interview) dengan responden dan pejabat terkait. Sedangkan data sekunder diperoleh Kecamatan Pesanggaran, Kelurahan Sumber Agung, serta dari studi pustaka dan studi literatur 
di berbagai instansi dan perguruan tinggi terkait tentang permasalahan masyarakat di potensi daerah pertambangan. Data sekunder Kelurahan Sumber Agung adalah data sebelum dilaksanakan kegiatan eksplorasi pertambangan dan data tehun 2013. Karena data ini untuk melihat adanya perubahan sosial ekonomi jenis mata pencaharian masyarakat.

C. Variabel Penelitian: Pengumpulan data primer dalam penelitian ini meliputi variabel-variabel sebagai berikut :

- Pengumpulan variabel karakteristik responden antara lain: karakteristik responden berdasarkan jenis kelamin, usia, tingkat pendidikan, pendapatan, jenis pekerjaan

- Pengumpulan Identifikasi pencaharian, pendapatan mengetahui gambaran tentang masalah-masalah sosial yang muncul.

Variabel-variabel yang digunakan dalam penelitian:

Table 1. Variabel

\begin{tabular}{|c|c|c|}
\hline \multicolumn{2}{|c|}{ No Nama Variabel } & Kode/Kategori \\
\hline \multirow{2}{*}{\multicolumn{2}{|c|}{$\begin{array}{l}\text { Variabel Respon }(Y): \\
\text { Variabel masalah } \\
\text { yang muncul } \\
\text { Variabel Responden }(X)\end{array}$}} & $1=$ positif $\quad 0=$ negatif \\
\hline & & \\
\hline$X 1$ & Umur & Kontinu \\
\hline$X 2$ & Jenis Kelamin & $1=$ pria $; 2=$ wanita \\
\hline$X 3$ & Suku & Berdasarkan suku-suku yang ada. \\
\hline$X 4$ & Pendidikan & $1=$ dibawah SD $2=$ SD s.d. SMP $3=$ SMA keatas \\
\hline$X 5$ & Agama & 1=Islam; 2=Katolik; 3=Kresten; 4=Hindu; 5=Budha \\
\hline X6 & Jenis Mata Pencaharian & $1=$ PNS, $2=$ Swasta, $3=$ Pedagang, $4=$ Petani, $5=$ Peladang \\
\hline$X 7$ & $\begin{array}{l}\text { Penghasilan rata-rata sebulan } \\
\text { (ribu rupiah) }\end{array}$ & $\begin{array}{l}1=0-500 \mathrm{rb}, 2=500 \mathrm{rb}-1000,3=1000 \mathrm{rb}-2000 \mathrm{rb}, 4=2000 \mathrm{rb}-3.000 \mathrm{rb} \\
5=>3000 \mathrm{rb} \text { (rupiah) }\end{array}$ \\
\hline$X 8$ & Lamanya bekerja & $1=<1$ thn $; 2=1-3$ thn $; 3=3-6$ thn $; 4>6$ thn \\
\hline$X 9$ & Kategori pekerja tambang & $\begin{array}{l}1=\text { t.k. kasar/kuli } 2=\text { t.k.tukang } 3=\text { t.k.mandor } 4=\text { t.k. manager } 5=\text { pemilik } \\
\text { PT. }\end{array}$ \\
\hline
\end{tabular}

\section{Sampel Penelitian}

Sampel dari penelitian ini adalah masyarakat yang berada di Desa Sumber Agung dan para pekerja tambang. Penelitian ini mengambil 100 orang dengan menggunakan teknik pengambilan random sampel secara purposive random sampling yaitu teknik yang sengaja dipilih untuk masyarakat dan pekerja tambang sesuai dengan tujuan penelitian. 


\section{E. Teknik Analisis Data}

Teknik analisis data yang digunakan dalam penelitian ini adalah analisis kritis interpretatif, causa-logical, dan deskriptive-analitik. Penelitian kualitatif ini disimpulkan setelah diperoleh proposisi-proposisi dasar dari hasil analisis sebelumnya.

\section{Hasil Penelitian dan Pembahasan}

Gambaran Umum Wilayah Penelitian
Kabupaten Banyuwangi salah satu Kabupaten yang berada di ujung Timur Propinsi Jawa Timur, dan mempunyai sumber daya alam beragam mulai dari daratan hingga perairan. Salah satu sumber daya yang mempunyai potensi yang menjanjikan bagi masyarakat saat ini adalah pertambangan emas yang berada di Desa Sumber Agung Kecamatan Pesanggaran.

Adapun luas wilayah Kecamatan Pesanggaran sebagai berikut dalam tabel di bawah ini.

Tabel 2. Luas Wilayah, Jumlah Penduduk, dan Tingkat Kepadatan Penduduk

\begin{tabular}{|c|l|l|l|c|}
\hline \multicolumn{5}{|c|}{ Tabel 2. Luas Wilayah, Jumlah Penduduk, dan Tingkat Kepadatan Penduduk } \\
\hline \multirow{2}{*}{ No } & Desa & $\begin{array}{l}\text { Luas } \\
\text { Wilayah }\end{array}$ & $\begin{array}{l}\text { Jumlah } \\
\text { Penduduk }\end{array}$ & $\begin{array}{l}\text { Kepadatan } \\
\text { (Km/jiwa) }\end{array}$ \\
\hline 2 & Sarongan & 47.04 & 5642 & 120 \\
& Kandangan & 18.06 & 8515 & 472 \\
4 & Sumber & 6.99 & 13636 & 1951 \\
4 & Agung & 2.63 & 14150 & 5380 \\
5 & Pesanggaran & Sumber & 6734 & 1194 \\
\hline
\end{tabular}

(Sumber : Kecamatan Pesanggaran dalam Angka, 2012)

Desa Sumber Agung yang menjadi desa penelitian merupakan desa yang mempunyai luas wilayah relatif kecil dari desa-desa dalam kecamatan namun mempunyai tingkat kepadatan penduduk cukup tinggi dan kepadatan penduduk relatif rendah ada di desa Sarongan, kepadatan penduduk yang tinggi ada di Desa Pesanggaran yang merupakan desa kota. Sedangkan jumlah penduduk berdasarkan karakteristik usia sebagai berikut dalam tabel di bawah ini.

Tabel 3. Jumlah Penduduk Berdasarkan Tingkat Usia di Kecamatan Pesanggaran

\begin{tabular}{|c|c|c|}
\hline No. & Usia & 2223 \\
\hline 1 & 0 - 9 Tahun & 2078 \\
2 & 10 - 19 Tahun & 1890 \\
3 & 20 - 29 Tahun & 2205 \\
4 & 30 - 39 Tahun & 2092 \\
5 & 40 - 49 Tahun & 1473 \\
6 & $50-59$ Tahun & 1675 \\
7 & 60 - >65 Tahun & 13636 \\
\hline
\end{tabular}

(Sumber : Kecamatan dalam Angka, 2012) 
Dari tabel 2 terlihat bahwa jumlah penduduk terbanyak ada di usia 30-39 tahun sebanyak 2205 jiwa dan jumlah paling sedikit ada di usia 50-59 tahun sebanyak 1473 jiwa.

\section{Deskripsi Penambangan Emas Bukit Tumpang Pitu}

Penambangan emas di kawasan Pesanggaran Banyuwangi dimulai dengan ditemukannya "Bukit Emas Tumpang Pitu" pada tahun 2006 yang diawali adanya survei dari investor Australia tahun 1999. Beberapa perusahaan yang pernah melakukan eksplorasi adalah Flaserdam, Hakma Metalindo, Indo Multi Niaga, dan sekarang perusahaan Bumi Sukses Indo. Keberadaan perusahaan dalam melakukan eksplorasi, juga telah mendorong masyarakat sekitar untuk mencari dan menemukan sendiri tambang emas yang ada di sekitar permukiman mereka. Salah satu narasumber memberikan informasi bahwa, penambangan emas secara tradisional dimulai ketika seseorang sedang menggali tanah untuk membangun rumah. Dari hasil galian pondasi rumah ternyata mereka menemukan butiran-butiran emas bercampur tanah dan bebetauan dari hasil galian. Sejak saat itu warga beramai-ramai menggali tanah di sekitar mereka hingga merambah ke lahan milik perhutani. Masyarakat beranggapan bahwa, "Jika tambang emas yang sedang diteliti pihak investor berada di Bukit Tumpang Pitu, maka keberadaan emas pasti juga dapat ditemukan di kawasan lainnya yang masih berdekatan dengan Bukit Tumpang Pitu". Sejak saat itulah berdatangan orang-orang dari berbagai daerah melakukan penambangan tradisional di sekitar Bukit Tumpang Pitu. Sejak saat itu perubahan drastis telah terjadi di Pesanggaran dan kawasan sekitarnya. Dampak yang ditimbulkan juga sangat besar sehingga situasi Desa Sumber Agung Kecamatan Pesanggaran seperti sebuah kota kecil yang tidak pernah sepi dan terus berdetak kegitannya selama 24 jam.

Desa Sumber Agung merupakan salah satu desa potensial yang ada di Kecamatan Pesanggaran. Keberadaan pantai Red Island (Pulo Merah) merupakan potensi lokal yang selalu menarik untuk dikembangkan dan menjadi icon tersendiri bagi Desa Sumber Agung sebagai desa wisata. Perubahan kehidupan masyarakat khususnya dalam bidang ekonomi semakin nyata ketika keberadaan perusahaan pertambangan yang melakukan eksplorasi membutuhkan banyak tenaga kerja dan kebutuhan akan tempat tinggal yang tidak jauh bagi pekerja perusahaan tambang. Di samping itu, anggapan masyarakat bahwa keberadaan tambang emas juga ada di sekitar permukiman penduduk membuat masyarakat melakukan penambangan secara tradisional atau bisa disebut illegal karena penambangan dilakukan di lahan-lahan dekat permukiman yang berada dalam pengelolaan perhutani.

Eksplorasi besar-besaran terjadi saat ditemukannya kandungan emas dalam bebatuan yang digali untuk pondasi rumah, berhubung adanya penemuan material tambang tersebut maka bukit itu sekarang terkenal dengan sebutan Bukit "Tumpang Pitu". Penemuan kandungan emas pertama sekali diperoleh pada kedalaman hanya 2 meter dalam tanah, sejak itu 
maka semakin banyak masyarakat yang mengadu nasib mencari emas di lokasi sekitar Bukit "Tumpang Pitu" tadi. Semakin lama semakin banyak orang yang ingin mencoba peruntungan mencari emas. Dulunya penduduk desa ini yang mengandalkan pertanian dan nelayan sebagai mata pencahariannya kini beralih menjadi pengelola, buruh penggali lobang, mandor, lansir, pemecah material batu emas, buruh gelondongan, dan berbagai kegiatan lain yang muncul akibat adanya penambangan batu mulia. Hingga saat ini wilayah ini banyak mengundang minat pendatang khususnya penambang yang berasal dari luar Banyuwangi. Adanya perusahaan yang mendapat ijin untuk eksplorasi di kawasan Bukit Tumpang Pitu Kecamatan Pesanggaran menambah semakin besarnya arus migrasi di Desa Sumber Agung yang letak desanya berada di sekitar area penambangan.

Pencari emas tidak hanya berasal dari Pesanggaran, tetapi banyak sekali yang datang dari daerah lain kecamatan lain dari Banyuwangi atau pun dari luar Banyuwangi seperti Bali, Probolinggo, Situbondo, dan Lumajang. Penambang emas ini bahkan ada yang berasal dari Lampung (propinsi Sumatera Selatan) dan Subang (Propinsi Jawa Barat). Masyarakat Sumber Agung Pesanggaran dan sekitarnya agaknya sangat terbuka terhadap perubahan dan keanekaragaman pendatang dari luar Pesanggaran. Pendatang hanya perlu melapor kepada perangkat desa dan selanjutnya mereka boleh langsung melakukan penggalian di lokasi penambangan. Derasnya arus keluar- masuk/ mobilitas penduduk serta aktivitas pertambangan menyebabkan aktivitas perdagangan barang dan jasa lain tumbuh dengan subur di Pesanggaran tersebut. Ketika kita memasuki kawasan ini maka kita akan menjumpai bengkel-bengkel sepeda motor, bengkel-bengkel las untuk pembuatan gelondongan, warung-warung makan, kedai kopi, kedai dan warung yang menyediakan kebutuhan tambang dtambah lagi dengan jejeran gelondongan pemecah batu yang memenuhi sepanjang jalan Pesanggaran.

Kondisi tersebut telah mengubah Pesangggaran menjadi seperti sebuah kota kecamatan yang lebih ramai dan lebih sibuk dari ibu kota kecamatan lainnya di daerah ini. Setiap hari akan dijumpai ratusan sepeda motor petambang dan pelansir material lalu lalang di jalan gampong, bunyi mesin gelondongan material emas seakan tidak pernah berhenti baik siang maupun malam, mobil pribadi atau pun mobil perusahaan tambang juga memasuki kawasan Bukit Tumpang Pitu. Meskipun bergerak dalam kegiatan penambangan yang bersifat instan dan spekulatif, harga-harga barangbarang dan jasa-jasa di Desa Sumber Agung Pesanggaran kawasan Bukit umpang Pitu tidak terlalu tinggi atau berbeda dengan tempat lain yang tidak ada tambang, ini terjadi karena lokasi gampong dengan ibukota kecamatan tidak jauh, lokasi penambangan juga tidak jauh dari gampong sehingga biaya transportasi tidak bertambah dan persaingan sesama penjual menyebabkan mereka tidak bisa semena-mena menentukan harga. Satu hal lagi yang menarik 
bahwa ada larangan dari perangkat gampong untuk tidak berjualan di lokasi penambangan tetapi hanya boleh di perkampungan agar kegiatan ekonomi lebih merata diperoleh dan dirasakan oleh seluruh masyarakat dan tidak menyebabkan kenaikan harga yang tinggi di lokasi penambangan.

Penambangan emas di kawasan Bukit Tumpang Pitu Kecamatan Pesanggaran sekitarnya menjadi lebih ramai dari sebelumnya, berbagai manfaat yang nyata telah dinikmati oleh masyarakat. Berdasarkan wawancara dengan perangkat desa dan perangkat kepemudaan, semua masyarakat di kawasan penambangan Bukit Tumpang Pitu tersebut sekarang bekerja dan memperoleh penghasilan dari tambang emas, apakah bekerja sebagai karyawan perusahaan atau menambang secara tradisional. Tidak hanya orang dewasa saja, anak-anak sekolah pada hari libur juga ikut menambang dan bekerja pada kegiatan penambangan. Hal ini dilakukan sebagai upaya untuk memberikan kesempatan bagi mereka memperoleh rahmat Tuhan dari adanya penemuan emas di lingkungan sekitar namun tetap menjaga lingkungan sekitar.

\section{Perkembangan Penambangan Bukit Tumpang Pitu}

Tambang emas di Petak 56 di lereng Bukit Tumpang Pitu, Desa Sumber Agung, Kecamatan Pesanggaran Kabupaten Banyuwangi yang sempat ditutup setelah peristiwa pembakaran peralatan pertambangan milik PT IMN, serta terjadinya penembakan beberapa warga yang dilakukan oleh aparat kepolisian beberapa bulan belakangan, kini telah dibuka kembali. Berbondong-bondong manusia datang mencari keberuntungan karena sebelumnya pernah mendengar cerita dari mulut ke mulut tentang orang-orang yang diuntungkan dari hasil keringat mereka di tempat yang sama.

Dari aspek perekonomian lokal, kegiatan pertambangan ini boleh dibilang cukup merangsang kelesuan pasar lokal yang sempat lesu ketika pertambangan rakyat ditutup karena kasus perusakan peralatan PT IMN dan penembakan aparat kepada beberapa penambang rakyat. Pasar kembali diramaikan oleh para penambang yang datang dari berbagai macam daerah. Para pedagang mulai dari sayur mayur sampai ke pedagang peralatan ringan yang dibutuhkan oleh para penambang untuk sementara boleh bergembira. Bahkan para pengijon yang menawarkan modal kepada para penambang dalam bentuk uang kontan sampai dalam bentuk kredit peralatan ringan, juga diuntungkan dengan dibukanya kembali pertambangan di Petak 56. Manusia lupa bahwa dalam konteks logika ekonomi segala kemungkinan hidup itu terbukti tidak pernah jauh dari hukum. siapa kuat dia menguasai. Dalam hal pencarian keberuntungan di Bukit Tumpang Pitu ini pun hukum yang sama masih berlaku. Jadi apakah Bukit Tumpang Pitu hanya akan memberikan berkah saja. Jawabnya tentu saja tidak, masih banyak faktor yang perlu diingat dan diperhatikan. Secara pengelolaan lingkungan hidup yang bertumpu pada konsep Ekologi manusia bahwa, lingkungan hidup terbagi 3 konsep yakni lingkungan hidup sosial, 
lingkungan hidup binaan, serta lingkungan hidup alamiah/ekosistem. Peran lingkungan hidup sosial dalam hal ini merupakan lingkungan yang sangat berperan terhadap dua konsep lingkungan lainya.

Penambang rakyat/tradisional dengan modal pas-pasan adalah kelompok lemah yang dikalahkan. Informasi tentang letak keberuntungan hanya mereka dapatkan dari mulut ke mulut yang ditunjang oleh dupa dan doa para dukun yang pamrih materi hasil produksi atau pun praproduksi yang tidak jarang membuat para penambang jatuh miskin dari konsultasi semacam ini. Peralatan yang mereka miliki hanyalah betel palu dan peralatan sederhana yang hanya membutuhkan tenaga manual manusia. Kalau pun mereka menggunakan pompa 'submersiveble'yang tidak murah itu, itu pun hanya bisa dimiliki oleh mereka yang memiliki sedikit modal awal dari usaha lain sebelum mereka jadi penambang. Hal lain yang perlu dipahami adalah bahwa kebanyakan dari penambang rakyat ini tidak begitu mengerti tentang jenis perbatuan dalam konteks geologi. Sehingga sering mereka berhadapan dengan ketidak beruntungan setelah menghabiskan begitu banyak harta kekayaan mereka sebelum menjadi penambang dan pulang dengan tangan hampa sebagai orang yang lebih miskin. Setelah survei dilakukan, terlihat bahwa metode pertambangan swasta ini dilakukan dengan metode "Underground" yakni dengan membuat terowongan di bawah Gunung Tumpang Pitu. Sepintas metode ini dipilih agar tidak menimbulkan kerusakan gunung. Sampai saat penelitian ini dilakukan (April, 2013) kondisi pertambangan swasta masih eksplorasi belum sampai eksploitasi.

Di sini letak ketidakberpihakkan ekonomi masyarakat di satu sisi dengan modal raksasa di sisi lain dengan modal konflik sosial keluarga sebagai modal dasar kegiatan penambang. Dalam suatu lobang tradisional biasanya dimiliki oleh kelompok dengan jumlah 3-4 orang. Pertama kegiatan pertambangan tidak mampu ditopang oleh satu orang untuk modal kegiatan, kedua masyarakat pada kemampuan pemahaman tentang tanah/geologi masih sangat dangkal, namun mereka lebih mengerti dengan insting saja mereka bisa mengetahui kandungan tanah mereka (wawancara dengan salah satu penambang tradisional, April 2013). Oleh karena itulah dalam berita-berita di media cetak selalu mengatakan bahwa kehadiran pertambangan di Gunung Tumpang Pitu membawa perpecahan sosial kekerabatan dan sosial kemasyarakatan. Penambang tradisional hanya berpikir bahwa memindahkan modal kerja selama ini yang digeluti ke aspek penggalian emas merupakan hal yang menggiurkan dan membawa keberkahan dan kehidupan yang lebih tinggi.

Memang tidak mudah untuk memahami tentang eksplorasi dan eksloitasi pertambangan yang akan didahului dengan modal besar. Anggapan mereka melakukan pekerjaan pertambangan lebih mudah dan lebih menjanjikan ekonomi daripada kegiatan pertanian dan perladangan. Penelitian ini berawal dari munculnya konflik sosial sebagai akibat dari masuknya kegiatan pertambangan emas di kawasan Gunung Tumpang Pitu. Penelitian ini 
berusaha untuk melihat sejauh mana perubahan ekonomi yang terjadi di masyarakat Desa Sumber Agung dalam waktu sepuluh tahun setelah dilakukannya kegiatan pertambangan baik dengan pertambangan tradisional maupun pertambangan swasta.

Dari sudut tinjauan ekonomi, daerah Banyuwangi mengalami perkembangan yang pesat dalam kurun waktu 5 tahun terakhir sebagaimana yang tercantum dalam tabel 3 . Berdasarkan data statistik yang dirilis Badan Pusat Statisik (BPS) kabupaten Banyuwangi tahun 2013, pertumbuhan ekonomi sumbangan sektor pertanian masih menduduki urutan pertama sebesar 46,05 persen, kemudian disusul oleh sektor perdagangan, hotel dan restoran kemudian sektor-sektor lainnya termasuk pertambangan memberikan rata-rata $26,8 \%$.

Tabel 4. Tingkat Pertumbuhan Ekonomi kabupaten Banyuwangi Tahun 2008-2012 (\%)

\begin{tabular}{|c|c|c|}
\hline No & Tahun & Pertumbuhan Ekonomi (\%) \\
\hline 1 & 2008 & 5,8 \\
2 & 2009 & 6,05 \\
3 & 2010 & 6,22 \\
4 & 2011 & 7,02 \\
5 & 2012 & 7,21 \\
\hline
\end{tabular}

(Sumber: BPS Kabupaten Banyuwangi dalam Angka Tahun 2013)

Perkembangan positif secara ekonomi tersebut juga semakin dirasakan masyarakat Pesanggaran, sejak ditemukannya sumber tambang emas di kawasan Bukit Tumpang Pitu sejak tahun 2006. Kegiatan pencarian dan penambangan emas telah membawa perubahan besar di daerah ini, baik yang dikelola perusahaan maupun oleh masyarakat yang dilakukan secara tradisional. Tambang emas di kabupaten ini telah banyak memberikan peningkatan ekonomi dan mendorong munculnya berbagai kegiatan ekonomi lain akibat multiplier effect dari penambangan tersebut, meskipun kegiatan ini juga menimbulkan dampak lain yang tidak terhindarkan seperti dampak sosial, budaya, dan lingkungan di sekitarnya.
Hasil Kajian Pemetaan Potensi Lokal dan

\section{Dampak Ekonomi Di Kawasan}

\section{Pertambangan Bukit Tumpang Pitu}

\section{a. Pemetaan Potensi lokal}

Dari hasil observasi dan survei di lokasi penelitian, berbagai potensi lokal yang menarik untuk dikembangkan bagi peningkatan perekonomian masyarakat dan pemerintah daerah adalah

- Banyaknya jumlah pendatang yang bekerja sebagai karyawan perusahaan eksplorasi tambang membuka kesempatan bagi masyarakat lokal untuk mengembangkan berbagai usaha ekonomi seperti; kostkosan, penginapan, warung, laundry (pencucian baju) katering, warnet, warung pulsa, dan usaha lainnya terkait pemenuhan kebutuhan harian karyawan.

Terdapat 4 (empat) RT dari RW 2 Desa Sumber Agung yang menjadi kantung- 
kantung hunian para pendatang baik yang bekerja sebagai karyawan perusahaan maupun penambang tradisional.
Berdasarkan data Kecamatan Pesanggaran dalam Angka tahun 2013 angka mutasi pendatang tercatat sebagai berikut:

Tabel 5. Angka Mutasi Pendatang di Kecamatan Pesanggaran

\begin{tabular}{|l|c|c|c|}
\hline \multirow{2}{*}{ Nama Desa } & \multicolumn{2}{|c|}{ Datang } & \multirow{2}{*}{ Total } \\
\cline { 2 - 3 } & Laki-Laki & Perempuan & 32 \\
\hline Sarongan & 12 & 20 & 59 \\
Kandangan & 28 & 31 & 72 \\
Sumber Agung & 43 & 29 & 228 \\
Pesanggaran & 154 & 74 & 92 \\
Sumber Mulyo & 51 & 41 & 483 \\
\hline Jumlah: & 288 & 195 & \\
\hline
\end{tabular}

(Sumber: BPS Kecamatan Pesanggaran dalam Angka Tahun 2013)

- Pengembangan usaha yang berkelanjutan seperti koperasi atau badan usaha lainnya menjadi kebutuhan bagi masyarakat yang mengelola berbagai usaha. Berdasarkan hasil in depth interview dengan pengelola usaha wisata pantai hingga saat ini belum ditemukan satu bentuk badan usaha yang menaungi usaha para pengelola baik kostkostan, penginapan, warung maupun usaha souvenir. Tabel 5 dan 6 menunjukkan perkembangan jenis-jenis usaha dan badan usaha yang ada di kecamatan Pesanggaran di mana Desa Sumber Agung dan Pesanggaran mengalami perkembangan yang pesat dengan jumlah jenis usaha yang lebih banyak dibandingkan desa lainnya.

Tabel. 6. Data Badan Usaha di Kecamatan Pesanggaran

\begin{tabular}{|l|c|c|}
\hline \multirow{2}{*}{ Nama Badan Usaha } & \multicolumn{2}{|c|}{ Tahun } \\
\cline { 2 - 3 } & 2011 & 2012 \\
\hline PT & 4 & 4 \\
CV & 3 & 2 \\
Koperasi & 0 & 0 \\
Parseorangan & 0 & 0 \\
\hline Jumlah: & 7 & 7 \\
\hline
\end{tabular}

(Sumber: Diolah dari data Kecamatan Pesanggaran dalam Angka Tahun 2012)

Tabel 7. Jenis-Jenis Tempat Usaha di Kecamatan Pesanggaran

\begin{tabular}{|l|c|c|c|}
\hline \multirow{2}{*}{ Nama Desa } & \multicolumn{3}{|c|}{ Jenis Tempat Usaha } \\
\cline { 2 - 4 } & Pasar & Toko & Warung \\
\hline Sarongan & 1 & 74 & 1 \\
Kandangan & 0 & 128 & 18 \\
Sumber Agung & 1 & 131 & 26 \\
Pesanggaran & 1 & 230 & 8 \\
Sumber Mulyo & 0 & 67 & 62 \\
\hline Jumlah: & 3 & 630 & \\
\hline
\end{tabular}

(Sumber: BPS Kecamatan Pesanggaran dalam Angka Tahun 2013) 
- Keberadaan pantai Red Island (Pulo Merah) merupakan potensi tersendiri yang dapat mendongkrak pendapatan masyarakat setampat dan pemerintah daerah. Posisi Kabupaten Banyuwangi sangat strategis karena terletak di ujung Pulau Jawa dan berbatasan dengan Provinsi Bali. Dalam Masterplan Percepatan dan Perluasan Pembangunan Ekonomi Indonesia (MP3EI), posisi Banyuwangi merupakan pintu gerbang Koridor Ekonomi Jawa sebagai "Pendorong Industri dan Jasa Nasional", yang menghubungkan dengan Koridor Ekonomi Bali Nusa Tenggara sebagai "Pintu Gerbang Pariwisata dan Pendukung Pangan Nasional”. Pada posisi ini, diharapkan Banyuwangi, dalam koridor ekonomi nasional ini menjadi 'pintu' untuk masuknya investasi. Harapan tersebut nampaknya semakin dekat dengan kenyataan. Dari data Badan Penanaman Modal Jawa Timur, jika sebelumnya minat investasi di Banyuwangi hanya menjadi rangking 31 diantara 38 Kabupaten/Kota di Jawa Timur, saat ini menempati posisi rangking ketiga sebagai daerah yang paling diminati investor setelah Gresik dan Surabaya. Dengan keberadaan investor, diharapkan bisa membangun sinergi positif demi kemajuan Banyuwangi ke depan. maskapai Wings Air telah membuka penerbangan BanyuwangiSurabaya PP setiap hari. Dengan demikian diharapkan akan semakin banyak investor yang tertarik untuk menanamkan modalnya di Banyuwangi.

- Investasi dan pertumbuhan ekonomi diharapkan memberikan dampak pada perluasan lapangan kerja, pengurangan pengangguran dan pengurangan kemiskinan. Pengurangan pengangguran ditunjukkan dari menurunnya Tingkat Pengangguran Terbuka (TPT). Pada tahun 2010, TPT di Banyuwangi mencapai 3,92 persen dari seluruh angkatan kerja. Kondisi ini membaik pada tahun 2011, tingkat pengangguran terbuka menurun mencapai 3,71 persen, berada di bawah TPT Jawa Timur yang mencapai 4,16 persen. Pada tahun 2009, prosentase penduduk miskin di Banyuwangi mencapai 12,16 persen penduduk. Kondisi ini membaik pada tahun 2010, penduduk miskin di Banyuwangi menurun mencapai 11,25 persen, berada di bawah penduduk miskin Jawa Timur yang mencapai 15,2 persen dan penduduk miskin nasional sebesar 13,33 persen penduduk. Investasi di Banyuwangi diharapkan mampu terus meningkatkan angka partisipasi angkatan kerja dan pada gilirannya mampu menurunkan pengangguran dan kemiskinan.

\section{b. Dampak Ekonomi}

Salah satu dampak ekonomi yang dirasakan masyarakat Desa Sumber Agung kecamatan Pesanggaran adalah banyaknya arus 
pendatang telah memberikan kontribusi besar dalam peningkatan bidang ekonomi masyarakat dalam rangka pemenuhan kebutuhan hidup dan terbukanya akses lapangan kerja di di luar sektor pertanian dan perikanan (nelayan) yaitu peluang kerja di perusahaan pertambangan, usaha warung, dan kost-kosan. Berdasarkan data BPS Kecamatan Pesanggaran Dalam Angka tahun 2013 memiliki luas wilayah $80.36 \mathrm{~km}^{2}$ dengan jumlah penduduk kecamatan Pesanggaran adalah: 48.677 jiwa dengan tingkat kepadatan $606 \mathrm{~km} / \mathrm{jiwa}$. Jumlah penduduk di wilayah studi (Desa Sumber Agung) adalah 13.636 jiwa dengan tingkat kepadatan 1.951 km/jiwa. Berdasarkan kajian data primer dengan 100 sampel yang diambil secara purposive bagi penduduk yang tinggal di sekitar kawasan penambangan Bukit Tumpang Pitu, diperoleh data $84 \%$ merupakan penduduk tetap dan $16 \%$ merupakan pendatang. Penduduk pendatang 16 orang tersebut berasal dari kabupaten Banyuwangi 4 orang, Kabuten Kediri 2 orang, kabupaten Malang 3 orang, 2 orang berasal Denpasar dan 3 orang Kecamatan Genteng, 2 orang dari Bandung.

\section{Kondisi Sosial Ekonomi Masyarakat di kawasan pertambangan}

Pekerjaan Responden

Berdasarkan data primer hasil wawancara dengan 100 responden, pekerjaan penduduk Desa Sumber Agung mengalami pergeseran komposisi pekerjaan yang belum terakomodir dalam data resmi BPS (Badan Pusat Statistik). Hasil penelitian menunjukkan bahwa jenis pekerjaan khususnya sebagai petambang sejumlah 12 orang (12\%) merupakan jenis pekerjaan yang saat ini banyak ditemui di Desa Sumber Agung baik sebagai penambang tradisional maupun pekerja tambang di perusahaan tambang di Bukit Tumpang Pitu.

Tabel 8. Jenis Mata Pencaharian Penduduk Desa Sumber Agung

\begin{tabular}{|l|l|c|c|}
\hline No & \multicolumn{1}{|c|}{ Jenis Pekerjaan } & Laki-laki & Perempuan \\
\hline 1 & Petani & 2684 & 3770 \\
2 & Buruh tani & 842 & 1006 \\
3 & Pegawai Negeri Sipil & 11 & 7 \\
4 & Pengrajin industri rumah tangga & 10 & 12 \\
5 & Pedagang keliling & 20 & 11 \\
6 & Peternak & 30 & 12 \\
7 & Nelayan & 200 & 150 \\
8 & TNI & 10 & 0 \\
9 & POLRI & 3 & 0 \\
10 & Pensiunan PNS/TNI/POLRI & 11 & 0 \\
11 & Dukun kampung terlatih & 0 & 4 \\
12 & Karyawan perusahaan swasta & 600 & 300 \\
13 & Makelar/Broker/Mediator & 10 & 0 \\
14 & Sopir & 24 & 0 \\
15 & Tukang cukur & 1 & 0 \\
16 & Tukang Batu/Kayu & 100 & 0 \\
\hline
\end{tabular}

(Sumber : Profil Desa Sumber Agung, 2012) 
Pertanyaan tentang pekerjaan sambilan sebelum ada tambang mayoritas responden $(41,7 \%)$ memilih untuk tidak menjawab yang berarti tidak punya pekerjaan sampingan, $22 \%$ menjawab kelompok pekerjaan yang sama yaitu petani,pekebun atau peternak : bukti ini mempertegas pula bahwa selain telah membuka lapangan pekerjaan yang baru, keberadaannya juga telah mengurangi masyarakat yang bekerja di sektor pertanian yang pada akhirnya nanti akan menyebabkan produsi sektor pertanian terutama tanaman pangan dan perkebunan akan menurun. Setelah bekerja di tambang emas, hasil kajian menunjukkan bahwa masing-masing responden lebih terpaku pada pekerjaannya baik itu sebagai pemilik/pengelola tambang, buruh atau penyedia barang/jasa terkait langsung dengan tambang, maupun penyedia barang/jasa lainnya. Kenyataan ini dipertegas pula dengan hasil kuesioner yang menunjukkan bahwa $66,7 \%$ responden tidak mengisi pilihan untuk pekerjaan sambilan di samping pekerjaan utamanya di tambang.

\section{Tingkat Pendapatan}

Penemuan emas telah pula menyebabkan adanya peralihan pekerjaan sebagian besar masyarakat Desa Sumber Agung dan masyarakat di sekitar Bukit Tumpang Pitu lainnya di sekitar tambang emas tersebut. Data kajian menunjukkan bahwa banyak sekali petambang awalnya memiliki pekerjaan sebagai petani/pekebun/peternak yaitu $63,9 \%$, kemudian buruh/tukang/karyawan swasta sebesar 19,4\%, dan sisanya untuk berbagai pekerjaan yang lain. Banyaknya peralihan pekerjaan dari petani dan pekebun berdampak pada lahan yang menganggur karena ditinggalkan untuk bekerja di tambang. Hasil produksi pertanian yang umumnya membutuhkan masa tunggu yang lama menyebabkan masyarakat lebih memilih ke tambang yang lebih instan dan dianggap lebih menguntungkan dengan nilai yang lebih menggiurkan.

Tabel 9. Tingkat Pendapatan Responden

\begin{tabular}{|l|c|c|}
\hline Pendapatan setiap bulan bulan & Jumlah responden & Prosentase \\
\hline < Rp. 1.500.000 & 42 & 42 \\
Rp. 1.500.000 - Rp. 2.500 .000 & 48 & 48 \\
Rp. 2.500.000 - Rp. 3.500.000 & 3 & 3 \\
Rp.3.500.000 - Rp. 4.500.000 & 1 & 1 \\
> Rp. 5.000.000 & 6 & 6 \\
\hline Jumlah & 100 & 100 \\
\hline
\end{tabular}

(Sumber: Hasil wawancara kuesiner responden, 2014)

$\begin{array}{rrrr}\text { Sebagian besar } & \text { responden telah } & \text { kesejahteraan yang sangat mencolok dibanding } \\ \text { menikmati perbaikan } & \text { ekonomi } & \text { dan } & \text { sebelumnya. Temuan di lapangan menunjukkan }\end{array}$


bahwa masyarakat yang bekerja di perusahaan pertambangan $28 \%$ mengalami peningkatan penerimaan pendapatan lebih tinggi dibandingkan dengan penambang tradisional yaitu $20 \%$. Meskipun telah terjadi peningkatan pendapatan namun masih banyak masyarakat yang belum mengelola keuangan untuk kebutuhan jangka panjang seperti menabung atau investasi. Masyarakat penambang, sesuai dengan kebiasaan di kawasan yang baru berkembang maka tambahan pendapatan pada awalnya lebih cenderung digunakan untuk kegiatan yang sifatnya konsumtif seperti membangun rumah yang baru atau merenovasinya, membeli kenderaan bermotor baru, menambah konsumsi alat-alat elektronik dan komunikasi yang lebih mahal dan lainnya. Maka tidak mengherankan rumah-rumah di Sumber Agung kecamatan Pesanggaran dan sekitarnya terlihat sebagian besar permanen, lebih besar dengan peralatan yang lengkap. Di kawasan Desa Sumber Agung jarang ditemukan kondisi rumah dengan kategori rumah prasejahtera.

Masyarakat petambang khususnya sangat sensitif bila mendengar adanya rencana penutupan areal penambangan, agaknya mereka telah terbiasa dan lebih menyukai bekerja di tambang dengan pendapatan dan kemungkinan pendapatan saat ini, oleh karena itu ketika dikonfirmasi tentang alternatif pekerjaan bila tambang ditutup atau tidak menghasilkan emas lagi, 30,6\% menjawab "tidak jelas" jenis pekerjaan yang akan dilakukan, berikutnya $27,8 \%$ tidak menjawab yang berarti juga tidak mempunyai gambaran terhadap masa depan pekerjaannya, sedangkan $22,2 \%$ responden akan mencoba peruntungannya pada usaha dagang/ wiraswasta, 16,7\% akan kembali ke pekerjaan asalnya yaitu pada sektor pertanian,kehutanan,dan perikanan serta 2,8\% responden memilih jenis usaha lain.

Jika dilihat dari tanggapan responden terhadap ketersediaan bahan baku produksi, 41,75\% responden mengatakan lancar dan tidak ada masalah dengan hal itu, 44,4\% mengatakan tersedia meskipun tidak begitu lancar, sedangkan $5 \%$ mengatakan tidak lancar. Responden yang menjawab tidak lancar ketika dikonfirmasi mengatakan bahwa lobang yang digali atau dikelola saat ini belum menghasilkan material tambang yang mengandung emas.

Terakhir, jika ditinjau dari aspek pemasaran maka mayoritas responden $(58,3 \%)$ menjawab lancar dan cepat terutama bagi pengelola dan buruh tambang yang tambangnya sedang menghasilkan kandungan emas. Emas yang sudah dipisahkan langsung bisa dijual karena pembeli sudah siap jemput bola dengan harga yang sangat bersaing karena

banyaknya penampung yang akan membeli emas di tempat itu.

Dari berbagai indikator ekonomi tersebut, maka dapat dilihat masyarakat Desa Sumber Agung dan di sekitarnya telah berubah secara drastis. Sebagian besar masyarakat dengan mata pencaharian utama pertanian, perkebunan atau peternakan telah berubah menjadi masyarakat petambang, efek luar biasa juga melebar ke berbagai kegiatan ekonomi 
lainnya, banyak sekali pekerjaan dan sumber pendapatan yang lain muncul akibat langsung maupun tidak langsung dari kegiatan pertambangan emas, maka tidaklah berlebihan bila kita sekarang menyebut kawasan sekitar penambangan emas di Pesanggaran menjadi sangat lebih baik perekonomiannya. Hal ini sesuai dengan penelitian yang dilakukan oleh Pasaribu (2010) terhadap dampak ekonomi tambang emas di kecamatan Batang Toru Tapanuli Selatan dan oleh Refles (2012) terhadap dampak penambangan emas di Kabupaten Sijunjung.

Tabel 10. Tingkat Penerimaan Masyarakat Di Kawasan Pertambangan

\begin{tabular}{|l|l|l|l|}
\hline \multirow{2}{*}{ Penerimaan Pendapatan } & Kategori & Penambang perusahaan & $\begin{array}{l}\text { Penambang } \\
\text { Tradisional }\end{array}$ \\
\cline { 2 - 5 } & Menurun & 10 & 12 \\
\cline { 2 - 5 } & Tetap & 12 & 18 \\
\hline & & N: 50 & N:50 \\
\hline
\end{tabular}

(Sumber: Hasil wawancara kuesioner responden, 2014)

Dampak ekonomi yang dirasakan masyarakat di kawasan pertambangan khususnya di Desa Sumber Agung kecamatan Pesanggaran adalah adanya perubahan mata pencaharian dari semula pekerjaan utama sebagai petani atau nelayan bergeser menjadi pekerja tambang baik sebagai pekerja tambang perusahaan maupun sebagai penambang tradisional. Hasil penelitian menunjukkan bahwa $63 \%$ dari responden menyatakan bahwa ada perubahan mata pencaharian,di mana masyarakat cenderung memilih pekerjaan sebagai pekerja tambang perusahaan atau pun sebagai penambang tradisional.

\section{c. Persepsi Masyarakat Terhadap}

\section{Keberadaan Tambang Emas}

Hasil penelitian juga menunjukkan bahwa setelah adanya kegiatan pertambangan dinyatakan oleh responden sebagai berikut:

Tabel 11. Pendapat Responden Terhadap Keberadaan Pertambangan

\begin{tabular}{|l|c|c|}
\hline Uraian & Jumlah & Prosentase \\
\hline biasa-biasa saja & 12 & 12 \\
masyarakat berkelu kesah & 35 & 35 \\
masyarakat bertambah guyub & 53 & 53 \\
\hline \multicolumn{2}{|c|}{ Jumlah } & 100 \\
\hline
\end{tabular}

Sejumlah $53 \quad(53 \%) \quad$ responden mengatakan kondisi masyarakat merasa suka dan senang karena kehidupan masyarakat bertambah guyub dan ramai desanya karena ada tambahan lampu PLN masuk ke wilayah ini sehingga jika malam hari desa bertambah ramai, sebanyak 35 (35\%) responden menyatakan masyarakat banyak yang berkeluh kesah/resah karena banyaknya 
karyawan dari luar daerah dengan perilaku yang beraneka ragam dan seringkali terlihat anak remaja yang bermabukkan/minum-minuman keras, sebanyak $12(12 \%)$ responden menyatakan biasa-biasa saja layaknya suatu kawasan yang ada perusahaan di dalamnya maka sedikit lebih ramai daripada tidak ada perusahaan.

Dengan kehadiran perusahaan pertambangan baik swasta maupun tradisional saat ini menunjukkan adanya dampak ekonomi secara nyata bagi masyarakat. Dari sebanyak 100 $\%$ responden ada sebanyak $42(42 \%)$ responden yang mengatakan bahwa rumah-rumah mereka sudah dikontrakan/disewa oleh perusahaan pertambangan tersebut. Rata-rata penyewa menurut responden mengontrakan paling sedikit 5 tahun, untuk kemudian diperpanjang kembali.

Aspek lain yang ikut dikaji adalah perspektif makro masyarakat terhadap keberlangsungan pertambangan emas, perasaan yang sudah dirasakan serta akibat baik-buruk yang akan dirasakan pada masa yang akan datang. Semua responden (100\%) yang terlibat dalam kajian ini menjawab setuju dengan keberadaan dan keberlangsungan pertambangan emas, argumen untuk mendukung jawaban setuju adalah penambangan tersebut telah mampu meningkatkan perekonomian terutama perluasan lapangan kerja dan peningkatan pendapatan ditambah peningkatan kesehatan yang lebih mampu mereka dapatkan akibat adanya tambahan pendapatan yang besar dari penambangan emas didaerah tersebut. Selain hal-hal tersebut diatas kemampuan responden mempersiapkan biaya pendidikan bagi anak-anak mereka menjadi lebih mudah sehingga diharapkan akan berpengaruh pada pendidikan generasi penerus di kawasan tersebut.

Pengalaman dan pengetahuan mereka tentang dampak penambangan emas sebelumnya di tempat lain juga menggambarkan bahwa dampak positif yang dihasilkan lebih besar. Terhadap dampak negatif, sebagian besar responden menjawab adalah kebisingan, polusi udara, dan polusi air bila kegiatan penambangan tidak diatur. Oleh karena itu mayoritas responden menginginkan campur tangan pemerintah untuk mengatur pola penambangan rakyat agar kemungkinan dampak negatif dari penambangan bisa ditanggulangi dan dikurangi.

Beberapa tokoh masyarakat dan perangkat Desa Sumber Agung menginginkan pemerintah menyetujui pembentukan sebuah kelompok koperasi usaha pertambangan yang dilegalkan oleh pemerintah untuk pengaturan dan pengorganisasian para petambang, namun masih terkendala beberapa peraturan yang belum mengatur tentang hal itu, namun sangat menolak bila pemerintah memberikan lahan tersebut untuk dikelola oleh perusahaan tertentu: karena akan menghilangkan kesempatan dan keuntungan langsung bagi penduduk dan kawasan tersebut. 
Pengetahuan dan Sikap Terhadap Keberadaan Tambang Tumpang Pitu Desa Sumber Agung

Pengetahuan menurut Sarlito, W (1996), adalah tingkat Kognitif/pemahaman manusia terhadap suatu obyek". Jika pengetahuan tersebut sudah masuk dalam pemahaman manusia maka disebut sebagai "sikap" manusia terhadap suatu obyek. Adapun tingkat pemahaman responden terhadap pertambangan

Tabel 12. Pemahaman Responden Terhadap Kehadiran Pertambangan

\begin{tabular}{|l|c|c|}
\hline \multicolumn{1}{|c|}{ Uraian } & jumlah & Prosentase \\
\hline pertambangan menjanjikan pendapatan yg baik & 52 & 30 \\
pertambangan membawa keberkahan & 42 & 24 \\
pertambangan prospek masa depan masyarakat & 33 & 19 \\
pertambangan menguntungkan masyarakat desa & 47 & 27 \\
\hline \multicolumn{2}{|}{} & 147 \\
\hline
\end{tabular}

(Sumber : Hasil Wawancara Kuesioner Responden, 2014)

Sebanyak $47 \quad(27 \%)$ responden menyatakan pertambangan menguntungkan masyarakat desa, sebanyak $33(19 \%)$ responden mengatakan pertambangan adalah prospek masa depan masyarakat, sebanyak $42(24 \%)$ responden mengatakan pertambangan membawa keberkahan, sebanyak $52(30 \%)$ responden mengatakan pertambangan merupakan pendapatan terbaik masyarakat di Kecamatan Pesanggaran ini.
Menurut wawancara peneliti kecamatan Pesanggaran ini sudah diketahui adanya potensi tambang emas sejak masa Orde Baru. Ketika Presiden Soeharto sudah pernah berkunjung ke kawasan ini dan menjanjikannya akan mengelola potensi emas yang berbasiskan masyarakat (wawancara dengan tokoh masyarakat, 2014). Lebih lanjut pernyataan responden tentang pertambangan tradisional adalah sebagai berikut:

Tabel 13. Pendapat Responden Terhadap Kegiatan Pertambangan

\begin{tabular}{|l|c|c|}
\hline \multicolumn{1}{|c|}{ Uraian } & jumlah & persentase \\
\hline merusak lahan pertanian & 12 & 12 \\
sama merusaknya dgn tambang swasta & 26 & 26 \\
berkah dari alam yg hrs diambil & 30 & 30 \\
bisa menguntungkan masyarakat & 32 & 32 \\
\hline \multicolumn{1}{|c|}{ Jumlah } & 100 & 100 \\
\hline
\end{tabular}

(Sumber: Hasil wawancara kuesioner responden, 2014)

Sebanyak $32 \quad(32 \%)$ responden mengatakan tambang tradisional menguntungkan masyarakat, sebanyak $30 \quad(30 \%)$ responden mengatakan pertambangan adalah berkah alam yang diberikan pada masyarakat Sumber Agung, sebanyak 26 (26\%) responden mengatakan baik tambang tradisional maupun Swasta sama-sama merusak alam hutan, sebanyak 12 (12 \%) responden mengatakan bahwa pertambangan merusak lahan-lahan perhutani. Lebih lanjut hasil wawancara responden tentang ekonomi rumah tangga dalam sepuluh tahun setelah adanya 
kegiatan pertambangan sebagai berikut dinyatakan.

Tabel 14. Kondisi Ekonomi Responden Setelah Ada Kegiatan Tambang

\begin{tabular}{|l|l|c|c|}
\hline No & Uraian & Jumlah & Prosentase \\
\hline 1 & Sama saja tidak ada perubahan & 20 & 20 \\
2 & Ada tambahan yang cukup banyak & 45 & 45 \\
3 & Ada tambahan dari rumah kontrak & 25 & 25 \\
4 & Kadang ada tambahan kadang tidak & 10 & 10 \\
\hline
\end{tabular}

(Sumber : Hasil wawancara kuesioner responden, 2014)

Sejumlah $45 \quad(45 \quad \%)$ responden

mengatakan ada tambahan yang cukup signifikan dengan kondisi saat ini, dan sebanyak 25 (25\%) responden mengatakan tambahan ekonomi yang diperoleh dari rumah mereka yang saat ini sedang di kontrak oleh Perusahaan tambang, sebanyak 10 (10\%) responden mengatakan ada tambahan dari rumah mereka kadang disewa oleh pengunjung yang ingin meneliti ataupun pengunjung yang datang untuk wisata selancar di Pulau Merah, serta ada sebanyak $20(20 \%)$ responden yang mengatakan tidak mendapatkan tambahan ekonomi. Responden ini masih trauma dengan penanaman modal untuk kegiatan tambang tradisional yang hingga saat ini belum bisa menutup seperti semula, ditunjang pula kegiatan ladang mereka saat ini sedang lesu akibat serangan serangga.

Kondisi perubahan ekonomi yang demikian ini dikatakan oleh Emil Salim (2002), bahwa perubahan sosial ekonomi dalam pembangunan masyarakat adalah kondisi sadar manusia dalam meningkatkan taraf hidupnya. Namun demikian tidak merubah konsep kelestarian lingkungan alam bumi kita demi keberlanjutan kehidupan manusia. Lebih lanjut dikatakan oleh Junaida (2014), dalam junal Urip Santoso tentang penelitian "Kaitan Kegiatan
Pertambangan Batubara dengan kebijakan Sosial”, bahwa seberapa pun besarnya kontribusi yang diberikan dari kegiatan pertambangan, jika tidak memberikan hasil dan manfaat yang nyata bagi masyarakat lokal maka usaha yang dilakukan tidak akan mencapai titik maksimal, bahkan mungkin masyarakat akan memberhentikan kegiatan operasi pertambangan.

\section{Simpulan dan Saran}

$\underline{\text { Kesimpulan }}$

Dari hasil pemetaan potensi di kawasan pertamabangan, teridentifikasi sejumlah potensi lokal yang menarik untuk dikembangkan. Sejak ditemukannya tambang emas di kawasan Bukit Tumpang Pitu dan keberadaan perusahaan BSI yang melakukan kegiatan eksplorasi dalam bidang pertambangan telah mendorong perkembangan ekonomi secara positif bagi masyarakat setempat. Penambangan emas di kawasan Bukit Tumpang Pitu Desa Sumber Agung kecamatan Pesanggaran kabupaten Banyuwangi telah menimbulkan dampak ekonomi secara nyata yang langsung dapat dirasakan oleh masyarakat sekaligus membuka peluang bagi pemerintah daerah untuk pengembangan ekonomi daerah.

Dari penelitian yang dilakukan, dampak nyata yang dirasakan masyarakat setempat adalah 
penambangan emas telah menyebabkan peralihan pekerjaan masyarakat menjadi penambang emas, peningkatan pendapatan, dan efek pengganda ekonomi terhadap kegiatan lainnya. Denyut nadi kehidupan juga mengalami perubahan yang sangat drastis, dimana sebelum ada kegiatan penambangan khususnya yang dilakukan perusahaan, kehidupan masyarakat Desa Sumber Agung tidak berbeda jauh dengan kehidupan masyarakat desa pada umumnya. Meskipun ada destinasi wisata pantai Pulo Merah (Red Island) di kawasan tersebut, kehidupan masyarakat biasa dimulai pagi hari dan berakhir sore hari. Namun sejak ada kegiatan penambangan, kondisi kehidupan berubah drastis sejak ada kegiatan penambangan di kawasan Bukit Tumpang Pitu Pesanggaran. Kehidupan sosial ekonomi masyarakat bergerak sepanjang hari atau bisa dikatakan 24 jam. Hilir mudik kendaraan bermotor para pekerja tambang silih berganti antara pekerja shift pagi-sore dengan pekerja tambang dengan shift kerja malam hingga pagi hari.

Dampak berikutnya adalah menjamurnya warung kopi-warung kopi yang buka hingga 24 jam untuk memenuhi kebutuhan sehari-hari pekerja tambang. Keberadaan tambang emas dan beroperasinya perusahaan (meskipun masih tahap eksplorasi) namun kondisi ini telah menimbulkan dampak lanjutan yaitu timbulnya arus migrasi penduduk dari berbagai daerah baik dari daerah lain yang masih berada dalam wilayah administratif kabupaten Banyuwangi maupun dari di luar, termasuk masuknya penduduk dari luar propinsi Jawa Timur. Keberadaan tambang emas di kawasan Bukit Tumpang Pitu Desa Sumber Agung kecamatan Pesanggaran telah membawa harapan baru dan peluang ekonomi yang menjanjikan bagi penduduk setempat dan pendatang dengan segala dampak sosial ekonomi yang mengikutinya dan hal ini membutuhkan kearifan dalam menerapkan kebijakan agar potensi lokal yang ada dapat dikembangkan secara optimal dan bermanfaat untuk kesejahteraan masyarakat dan peningkatan ekonomi daerah secara berkelanjutan.

\section{Saran}

Berdasarkan hasil penelitian, dibutuhkan adanya payung Regulasi untuk pengelolaan Pertambangan yang Berwawasan Lingkungan. Melihat maraknya kegiatan pertambangan dalam satu kawasan Kecamatan Agraris yang sudah mulai mengalami perubahan menjadi kawasan pertambangan. Kekhawatiran terhadap pengalihan fungsi kawasan hutan konservasi berubah menjadi hutan produksi bisa mengakibatkan degradasi lingkungan kawasan jika tidak terpayungi dalam regulasi yang mengikat.

\section{Keterbatasan Penelitian}

- Periode waktu pengamatan dan observasi dalam penelitian ini terfokus pada satu tempat, sehingga tidak ada pengamatan kawasan pertambangan di tempat lain

- Perusahaan Pertambangan yang saat ini sedang beroperasi relatif masih kurang baik untuk berkomunikasi, sehingga masih kurang banyak data yang bisa kami akses. 


\section{Daftar Pustaka}

Chamid. Chusharini. 2006. Keberhasilan Program Community Development di Sekitar Tambang Mencerminkan Kinerja Industri Pertambangan. Jurnal MIMBAR. Jurnal Sosial dan Pembangunan. ISSN 028-175 EISSN 2303-2499 (terakreditasi).

Junaida. 2014. Kaitan Kegiatan Pertambangan Batubara dengan Kebijakan Sosial. Jurnal Urip Santoso. Vol. 5 No.01 tahun 2014.

Kustanti. Sukriyah. Endang Susilowati. 2011. Pemberdayaan Masyarakat Pemulung (Studi Kasus Masyarakat Pemulung TPA di Benowo) Kota Madya Surabaya. Jurnal Sosial

Humaniora (Jsh). Volume 5. Nomor 1. UPM Soshum ITS.

Miranti, Ermina. 2008. Prospek Industri Batu Bara di Indonesia. Jurnal Economi. Review No. 214.

Puluhulawa. Fenti.U. 2011. Pengawasan Sebagai Instrumen Penegakan Hukum Pada Pengelolaan Usaha Pertambangan. Jurnal Dinamika Hukum. Volume 11 No.2.

Zaki,A.R, Abdul Hakim, Farida Nurani. 2012. Dampak Sosial Ekonomi Pertambangan Minyak Dan Gas Banyu Urip Kabupaten Bojonegoro (Studi pada Masyarakat Desa Gayam Kecamatan Gayam Kabupaten Bojonegoro). Jurnal Administrasi Publik
(JAP), Volume 1 No. 2 hal 125-131. Fakultas Ilmu Administrasi Universitas Brawijaya.

Zulkifli, 2013. Analisis Dampak Ekonomi, sosial Budaya dan KesehatanMasyarakat Akibat Penambangan Emas. Jurnal Ekonomi Pembangunan Volume IV no 7. Maret 2013 ISSN : 2086-6011.

Dinas Pertambangan Kabupaten Banyuwangi tentang Potensi Pertambangan di Kecamatan Pesanggaran, 2010-2011.

Hasil Penelitian Laboratorium Pertanian UGM, 2011, Tentang Pemetaan Masyarakat Desa di Jawa Tengah.

Pasaribu, Arman. (2010). Analisis Dampak Pertambangan Emas Terhadap Sosial Ekonomi masyarakat di Kecamatan Batang Toru Kabupaten Tapanuli Selatan, Sekolah Pascasarjana Universitas Sumatera Utara.

Refles. (2012). Kegiatan pertambangan Emas Rakyat dan Implikasinya terhadap Kondisi Sosial Ekonomi Masyarakat di Kanagarian Mundam Sakti kecamatan IV Nagari, kabupaten Sijunjung, Artikel Penelitian, Program Pascasarjana Universitas Andalas. 